\title{
Thermal Behavior of Aqueous Cerium Oxide Nano-Suspension under the Pool Boiling Conditions
}

\author{
Doğan ÇíLOĞLU1
}

\begin{abstract}
The present paper focuses on an experimental study of pool boiling characteristics of cerium oxide $\left(\mathrm{CeO}_{2}\right.$, ceria) nano-suspension on a horizontal flat copper surface at atmospheric pressure. The nanofluid suspension is prepared by a two-step method and stabilized using Na-citrate, $\mathrm{pH}$ setting and ultrasonic vibration as well. The effect of applied heat flux to the boiling surface on pool boiling heat transfer coefficient (HTC) of cerium oxide nanofluid is experimentally examined and briefly discussed. The results illustrate that the pool boiling HTC increases with using cerium oxide nanofluid as working fluid. Also, the results show that the critical heat flux for cerium oxide nanofluid having 0.1 vol. $\%$ nanoparticle concentration improves up to $103 \%$ compared with the deionized water.
\end{abstract}

Keywords: Cerium oxide, critical heat flux, heat transfer, nanoparticles, pool boiling

\section{Havuz Kaynama Şartlarında Su-bazlı Cerium Oksit Nano-süspansiyonunun Termal Davranışı}

ÖZET: Bu çalışma, atmosfer basıncı altında yatay bir bakır plaka üzerinde cerium oksit $\left(\mathrm{CeO}_{2}\right.$, ceria $)$ nanosüspansiyonunun havuz kaynama karakteristiklerinin deneysel olarak incelenmesi üzerine gerçekleştirilmiştir. Nano akışkan süspansiyonu iki adım metodu ile hazırlanmıştır ve Na-citrate ilavesi, pH ayarı ve ultrasonik titreşim uygulanarak kararlı hale getirilmiştir. Cerium oksit nano akışkanının havuz kaynama ısı transfer katsayısı üzerine kaynama yüzeyine uygulanan isı akısının etkisi deneysel olarak incelenmiş ve sonuçlar tartışılmıştır. Deneysel sonuçlar, iş yapan akışkan olarak cerium oksit nano akışkanının kullanılması ile havuz kaynama 1sı transfer katsayısının arttığını göstermiştir. Ayrıca elde edilen sonuçlar, de-iyonize su ile karşılaştırıldığında, \%0.1 hacimsel konsantrasyona sahip cerium oksit nano akışkanı için kritik 1sı akısında \%103 artış olduğunu göstermiştir.

Anahtar kelimeler: Cerium oksit, havuz kaynama, 1sı transferi, kritik ısı akısı, nano partikül

Doğan ÇiLIOĞLU (0000-0002-7570-9271), Atatürk Üniversitesi, Erzurum Meslek Yüksekokulu, Elektrik ve Enerji Bölümü, Erzurum, Türkiye Sorumlu yazar/Corresponding Author: Doğan ÇíLOĞLU, dciloglu@atauni.edu.tr 


\section{INTRODUCTION}

Boiling heat transfer has a wide application area in cooling systems and power cycles. The efficiency of these systems depends on the thermal properties of the working fluid. In a boiling phenomenon, critical heat flux (CHF) is the limited point where overheating problem occurs due to the vapor bubbles fully covered to the heating surface. In this condition, the heat cannot be conveyed from the surface to the surrounding fluid and can finally damage the surface. Therefore, CHF is an undesirable phenomenon and it should be prevented. Recently, nanofluids have been used in many experimental and theoretical studies by the researchers. The researchers have determined that they provide useful advantages to improve the thermal properties of systems and a good option for the goal of CHF prevention (Bang and Chang, 2005; Sheikhbahai et al., 2012; Shahmoradi et al., 2013; Ciloglu and Bolukbasi, 2015). Therefore, the nanofluids can be used for ultra-high heat flux electronic and aerospace applications and in advanced cooling systems as an efficient coolant (You et al., 1994; Kim et al., 2007; Harish et al., 2011; Okawa et al., 2012; Ahmed and Hamed, 2012).

Nanofluids are prepared as a colloidal suspension comprised of solid particles $>100 \mathrm{~nm}$ dispersed into the conventional fluid such as water, ethylene glycol or engine oil. The most commonly used nanoparticles for nanofluids are generally metals (e.g., $\mathrm{Cu}, \mathrm{Al}$ and $\mathrm{Ag}$ ), ceramics (e.g., $\mathrm{Al}_{2} \mathrm{O}_{3}$, $\mathrm{CuO}, \mathrm{SiO}_{2}$, and $\mathrm{TiO}_{2}$ ) or other materials (e.g., $\mathrm{SiC}$ and carbon nanotubes).

The present worldwide manufacture of cerium oxide nanoparticles is estimated to be ten thousand tons. Cerium oxide nanoparticles producers are sited worldwide. The main industrial segments in which cerium oxide nanoparticles expertise is probable to be working are electronics, catalysts, optics, environment, energy, paints and coatings (Keller et al., 2013; Collin et al., 2014). The use of cerium oxide nanoparticles fluids for enhancing the thermo-physical has shown to be important in applications such as fuel cells, heat exchanger, heat transfer, tribology, coolant material, UV absorbent, filters and metal polishing (Herna'ndez et al., 2008; Ngoc et al., 2011; Zhao et al., 2013; Tiwari et al., 2013). Although many studies have been performed to investigate the pool boiling behavior of many types of nanofluids, there are limited number of studies on cerium oxide nanosuspensions. Therefore, this study may guide the investigators to encourage studies on the cooling application of this nanofluid.

In this study, the experiments are carried out to determine the pool boiling HTC and CHF value of cerium oxide aqueous nanofluid. The effect of heat flux applied to the boiling surface on pool boiling HTC of cerium oxide nanofluid is experimentally examined and briefly scrutinized.

\section{MATERIAL AND METHOD}

\section{Experimental Setup}

A schematic of the experimental facility used in this study is shown in Figure 1a. The test facility has several major components such as a boiling vessel, heating section and the data acquisition system. The boiling vessel made of borosilicate glass has dimensions $\varnothing 100 \times 200 \mathrm{~mm}$. To operate at atmospheric pressure, a valve was mounted on the Teflon lid of the boiling vessel. To condense the generated vapor, a coil condenser is used on the lid and therefore to keep constant the volume concentration of the nano-suspension. Figure $1 \mathrm{~b}$ illustrates the details of the copper block placed at the bottom of the vessel. The boiling takes place on the upper end of its $38 \mathrm{~mm}$ in diameter that the heat transfer area is $11.34 \mathrm{~cm}^{2}$. The uniform temperature distribution on the surface has been proved by numerical analysis of another author's work (Ciloglu, 2017). Prior to each test the boiling surface is mechanically polished using SiC emery paper with different grades and then with $\alpha$-alumina for mirror finish. The test surface is finally rinsed with deionized (DI) water. 


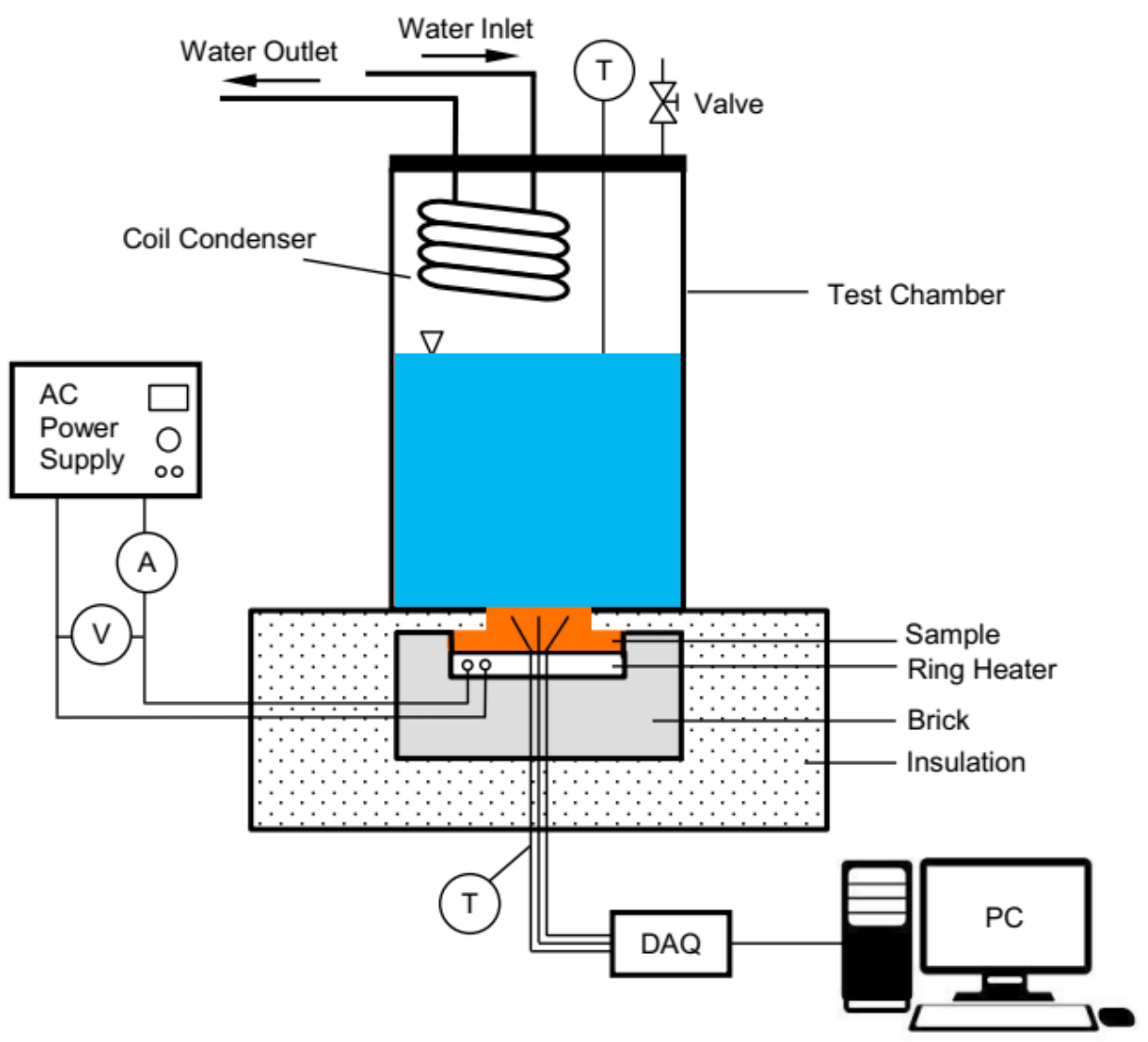

(a)

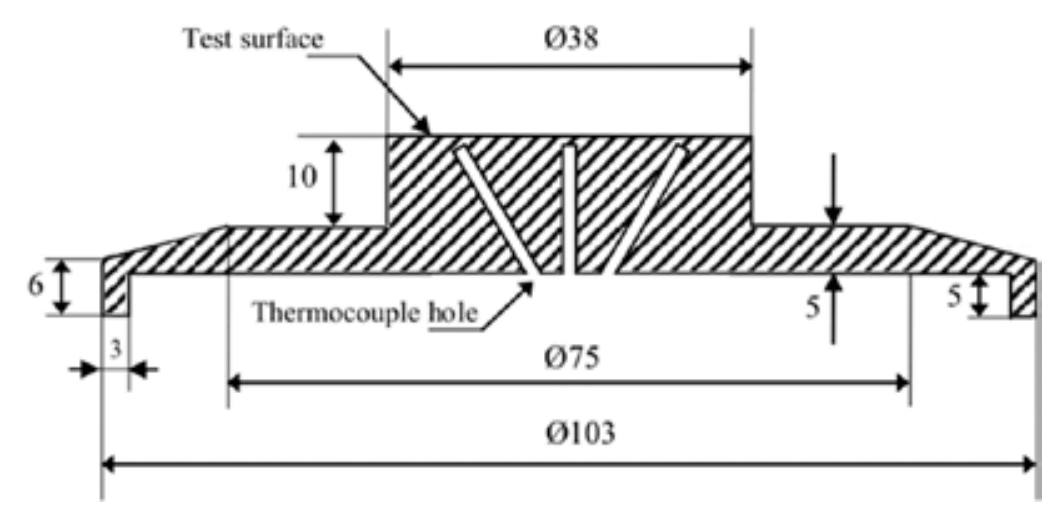

(b)

Figure 1. (a) Schematic diagram of experimental setup; and (b) the details of the copper block. All dimension is based on mm

To measure the surface temperature, three K-type thermocouples are mounted $2 \mathrm{~mm}$ below the test surface at different locations and another is vertically fitted into the boiling vessel to record the bulk fluid temperature, as illustrated in Figure 1a. Taking into account a small temperature drop across the distance of $2 \mathrm{~mm}$ between the thermocouples and boiling surface, the surface temperature 
obtained from the mean of three thermocouples is estimated by extrapolation using the Fourier's law.

The uncertainty of the temperature measurement is $\pm 0.1^{\circ} \mathrm{C}$. The history of time, surface and fluid temperature is recorded using the data acquisition system (National Instruments, NI USB-6363).

The sealing between the specimen and the boiling vessel is provided by a silicone seal resistant to high temperature. An $\mathrm{AC}$ heater with a maximum power capability of $2.5 \mathrm{~kW}$ is closely embedded to the backside of copper block and the heat flux was controlled changing the voltage via $5 \mathrm{~kW}$ AC power supply. The copper block and AC heater are placed on a refractory brick.

The surroundings of them are well isolated by a rock wool to diminish the lateral heat loss and to transfer the heat flow towards the test surface.

\section{Preparation of Cerium Oxide Nano- suspension}

Collection of plant sample and preparation of plants extract and partially purification of peroxidase enzyme: Euphorbia (Euphorbia amygdaloides) plant shown in Figure 2 was collected from Erzurum, Turkey, and it was recognized with the help of taxonomists. Plants were washed with distilled water several times. Then, Euphorbia was cut into small parts. The parts $(50 \mathrm{~g})$ were thoroughly shattered to form a homogeneous mixture in blander by using $500 \mathrm{~mL}$ of $10 \mathrm{mM}$ sodium phosphate buffer (pH:6). It was centrifuged at $9000 \mathrm{rpm}$ for $10 \mathrm{~min}$ and the supernatant was used for next step. Prepared Euphorbia plant homogenate was saturated from 60 to $80 \%$ with ammonium sulphate and the partially purification of peroxidase enzyme was used for synthesis cerium oxide nanoparticles (Alayli et al., 2008; Cicek et al., 2015).

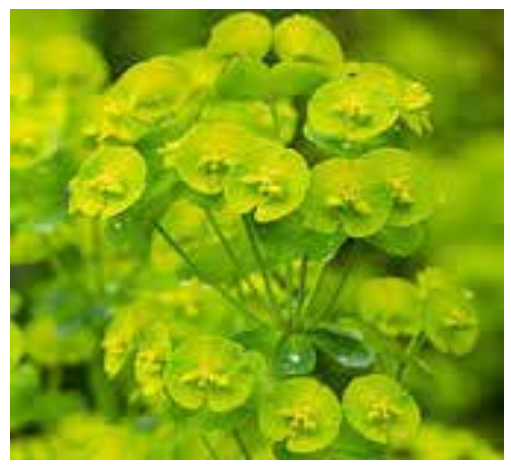

Figure 2. Photograph of Euphorbia (Euphorbia amygdaloides) plant

Synthesis of cerium oxide nanoparticles and preparation of nano suspension: $300 \mu \mathrm{L}$ of peroxidase enzyme was added in a sample of cerium sulfate solution $\left(\mathrm{CeSO}_{4}\right)(10 \mathrm{~mL}, 10 \mathrm{mM})$ and it was incubated for the reaction mixture in a closed space for 4 hours. The solution was turning from dark yellow to light yellow and this change indicated the presence of cerium nanoparticles. Then, water in the reaction medium was removed with the help of an evaporator and synthesized cerium oxide nanoparticles were dried at $60^{\circ} \mathrm{C}$ for 24 hours (Bindhu and Umadevi, 2013; Vahabi and Dorcheh, 2014)

The nanofluids were prepared using two-step method. The obtained cerium oxide nanoparticles (0.1 vol.\%) were prepared using DI water containing
Na-citrate $(0.1 \mathrm{wt} . \%)$ and its $\mathrm{pH}$ value was adjusted to be 10.0 using $1 \mathrm{M} \mathrm{NaOH} / 1 \mathrm{M} \mathrm{HCl}$. Barton et al. (2014) suggested that the cerium oxide nanoparticles act as a coagulant at higher concentrations. The improved colloidal constancy of the citratefunctionalized nanoparticles in the supernatant descriptions reduced removal to the solids with higher concentrations. In order to increase the stability of solutions, the suspension is also put in an ultrasonic bath (Everest Ultrasonic, model Clean Ex 1211) for about $2 \mathrm{~h}$ just before the experiment. Consequently, the final nano-suspension exhibited high colloidal constancy. The TEM image and the sample photo of cerium oxide nano-suspension with the volume concentration of 0.1 vol.\% are shown in Figure 3. 


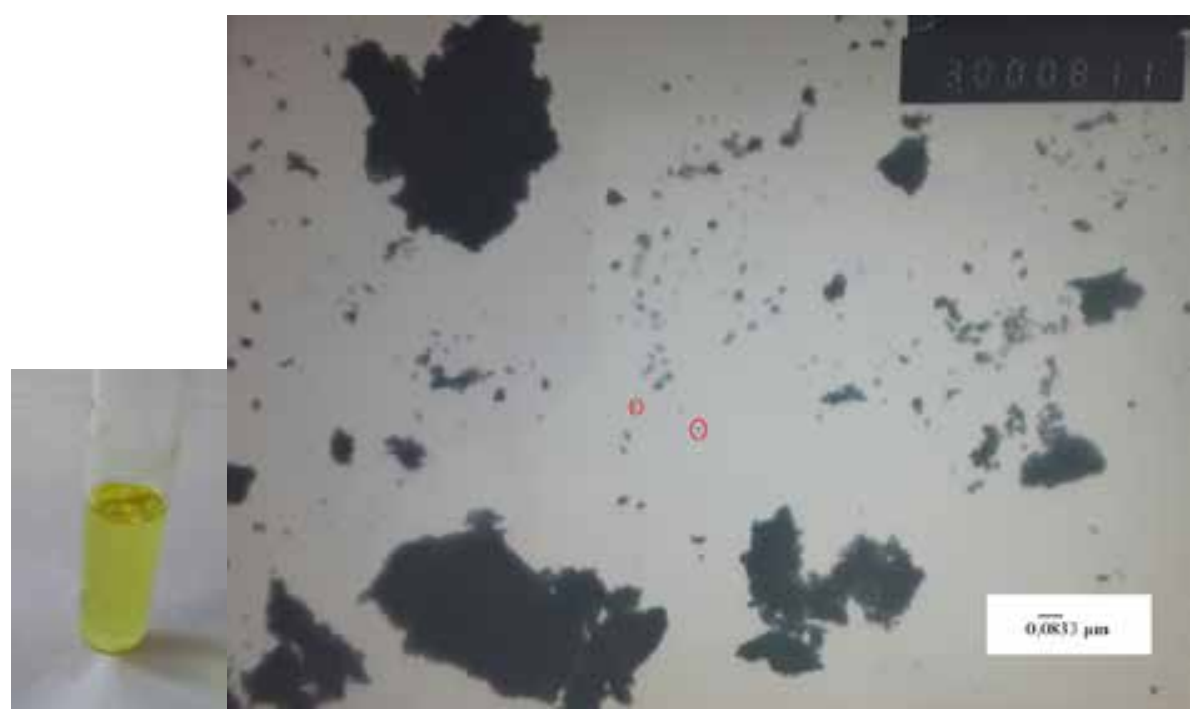

Figure 3. TEM and sample photograph of cerium oxide nanoparticle suspension ( $0.1 \mathrm{vol} . \%)$

\section{Experimental Procedure}

The experiments in the present study were carried out at atmospheric pressure and saturated temperature for all the working fluids with the concentration of $0.1 \mathrm{vol} . \%$. In each run, the fluid was loaded into the boiling vessel. The power was then gradually raised by an increment of $5 \%$ until the fluid reached the saturation temperature $\left(92^{\circ} \mathrm{C}\right)$ and a steady state. In the experiments, approximately $10 \mathrm{~min}$ was required to reach the steady state condition which was a thermal equilibrium between the specimen and the fluid. Once this condition was reached, the input voltage and current was measured and saved by using two multi meters. The power was increased in small increments of $2 \%$ at closed to the expected CHF. This procedure continued until the CHF was taken place. When the CHF occurred, the vapor layer on the surface formed and the surface temperature quickly increased. At the moment, the power was suddenly shut down and the test was finished to inhibit any equipment failure. The boiling vessel was cleaned and reloaded for different runs. In each test, a clean test surface and fresh nanofluid were utilized. For all boiling tests, the measurements were taken at least three times to check the repeatability.

In a typical boiling phenomenon, at low heat fluxes, the predominant mechanism is the natural convection where the vapor bubbles are not taken place on the heating surface. However, at high heat fluxes, the vapor bubbles are generated owing to the bubble interactions and its transport, and so the nucleate boiling starts. In these conditions, the rate of heat transfer importantly increases and an instantaneous decrease of surface superheat is observed. The nucleate boiling goes on till the CHF is reached (Sarafraz and Hormozi, 2014). Then, the temperature of the copper block instantly rises because the transition and film boiling regime happen. In this case, the power is rapidly turned off, and the heat flux value at this point is defined as CHF. The voltage and current readings are recorded by increasing the power of the heater for each step. The data obtained are used to create the boiling curves.

\section{Data Reduction and Uncertainty}

The heat flux is calculated by:

$$
\mathrm{q}^{\prime \prime}=\mathrm{VI} / \mathrm{A}
$$

where V is the voltage, I is the current and A is the surface area. The boiling HTC is calculated as follows:

$$
\mathrm{h}=\ddot{\mathrm{q}} /\left(\mathrm{T}_{\mathrm{s}}-\mathrm{T}_{\mathrm{sat}}\right)
$$


where $\mathrm{T}_{\mathrm{s}}$ and $\mathrm{T}_{\text {sat }}$ are the surface and the saturation temperature, respectively. The experimental uncertainty is determined using the error propagation analysis (Buchanan and Turner, 1992). Maximum uncertainties in the current and voltage are less than $1 \%$. The uncertainties in the heat fluxes are calculated to be $14.5 \%$ and $8.3 \%$ as the lowest and highest heat fluxes, respectively.

\section{RESULTS AND DISCUSSION}

Figure 4a shows the effect of heat flux on the boiling characteristic of cerium oxide nanofluid at $0.1 \mathrm{vol}$. \%. It is noted that the heat flux increases regularly with the surface superheat till the CHF point. From this figure, it can be concluded that the cerium oxide nanofluid exhibits $105 \%$ improvement in CHF $\left(868 \mathrm{kWm}^{-2}\right)$ as compared to that of DI water $\left(423 \mathrm{kWm}^{-2}\right)$.

Figure $4 \mathrm{~b}$ depicts the variation of the heat flux versus the pool boiling HTC in nucleate boiling condition. It is seen that from this figure, the heat flux has a considerable effect on the pool boiling HTC. Namely, the pool boiling HTC dramatically increases as the applied heat flux increases.
The experimental results of this study are compared with the results in the literature. For example, Shahmoradi et al. (2013) also declared a 47\% enhancement in CHF of $\mathrm{Al}_{2} \mathrm{O}_{3}$ /water on a copper block having $38 \mathrm{~mm}$ diameter. In another study, Okawa et al. (2012) studied the boiling heat transfer for $\mathrm{TiO}_{2} /$ water nanofluids on a copper block with $20 \mathrm{~mm}$ diameter. They explained a $91 \%$ enhancement in CHF. Raveshi et al. (2013) also clarified a 64\% enhancement in the heat transfer coefficient of water-EG based $\mathrm{Al}_{2} \mathrm{O}_{3}$ nanofluids on a copper cylinder of $40 \mathrm{~mm}$ diameter. As a result, a considerable increment in the $\mathrm{CHF}$ value of present nanofluid (103\%) is obtained in this study.

A thin, weakly attached and easily removable layer of yellow nanoparticles is seen on the test surface after the pool boiling experiments with nanofluids. The some peculiarities of this nanoparticle layer including the effect of the surface roughness and the wettability can be facilitated to comprehend the fundamental phenomenon of the improvement in the pool boiling HTC and CHF (Liu and Qiu, 2007; Mourgues et al., 2013; Ciloglu et al., 2015; Ciloglu and Bolukbasi, 2015). The next research will be to determine the influences on the boiling heat transfer of the nanoparticle concentration and this nanoparticle layer.
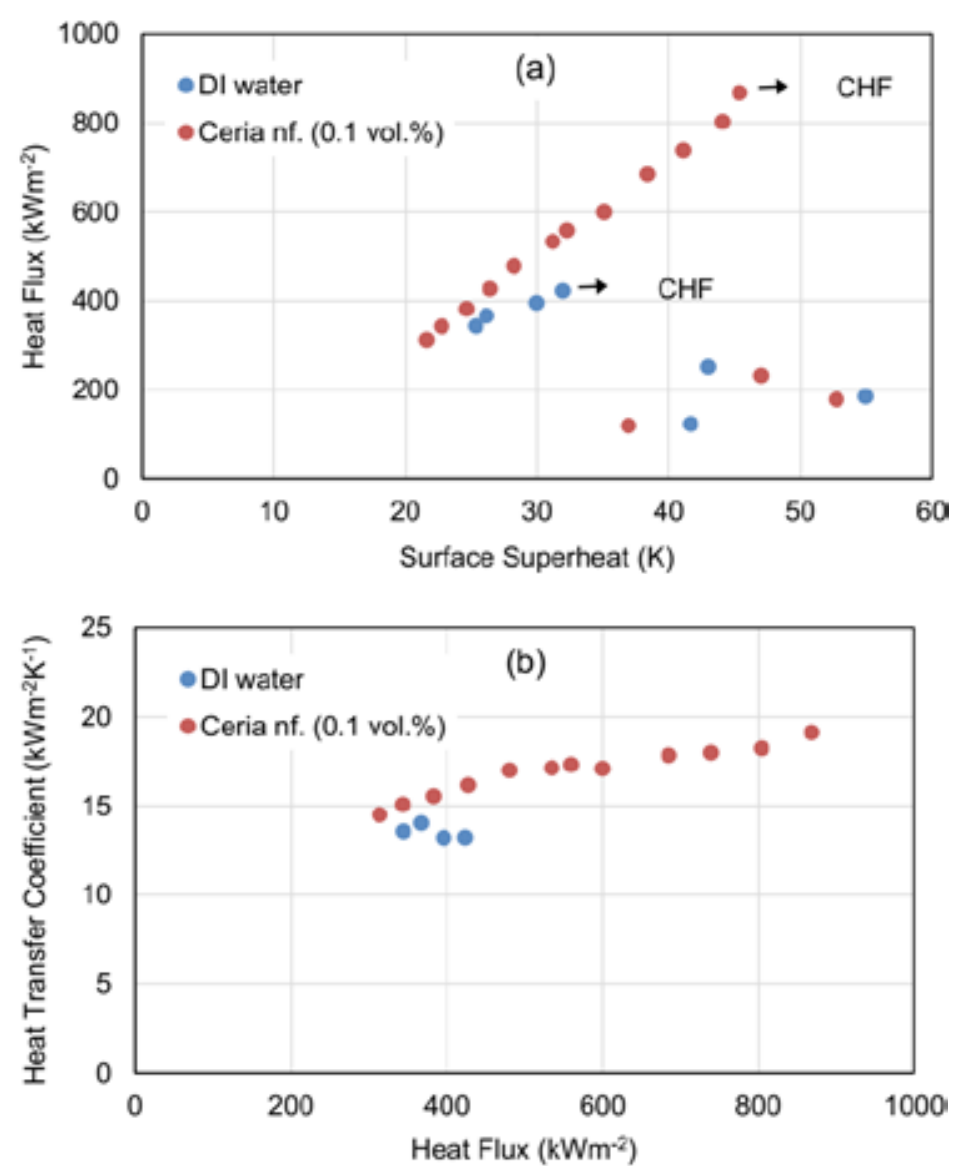

Figure 4. Boiling curves of cerium oxide nanofluid with the DI water (a) Surface superheat vs. heat flux; and (b) heat transfer coefficient vs. heat flux 


\section{CONCLUSION}

The pool boiling behavior of cerium oxide nanosuspension with the nanoparticle concentration of 0.1 vol.\% is experimentally investigated using the upper side of copper block with $38 \mathrm{~mm}$ diameter. The experiments are carried out under saturated and atmospheric conditions. The following conclusions have been made:

- It was seen that HTC can be improved with incorporation the solid nanoparticles in comparison with the DI water.

- Rate of enhancement can be intensified with increasing applied heat fluxes.

- The maximum increment of CHF is determined to be $103 \%$ for cerium oxide nanofluid compared to DI water.

\section{REFERENCES}

Ahmed O, Hamed MS, 2012. Experimental investigation of the effect of particle deposition on pool boiling of nanofluids. Int. J. Heat Mass Transf., 55: 3423-3436.

Alayli GA, Demir Y, Demir N, 2008. Purification of peroxidase from latex of Euphorbia (Euphorbia amygdaloides) and investigation of kinetic properties. Asian J. Chem., 20: 477-482.

Bang IC, Chang SH, 2005. Boiling heat transfer performance and phenomena of $\mathrm{Al}_{2} \mathrm{O}_{3}$-water nano-fluids from a plain surface in a pool. Int. J. Heat Mass Transfer, 48: 2407-2419.

Barton LE, Auffan M, Bertrand M, Barakat M, Santaella C, Masion A, Borschneck D, Olivi L, Roche N, Wiesner MR, Bottero JY, 2014. Transformation of pristine and citrate-functionalized $\mathrm{CeO} 2$ nanoparticles in a laboratory-scale activated sludge reactor. Environ. Sci. Technol., 48: 7289-7296.

Bindhu MR, Umadevi M, 2013. Synthesis of monodispersed silver nanoparticles using Hibiscus cannabinus leaf extract and its antimicrobial activity. Spectrochim. Acta Part A: Mol. Biomol. Spectrosc., 101: 184-190.

Buchanan JL, Turner PR, 1992. Numerical Methods and Analysis. McGraw-Hill, New York.

Cicek S, Gungor AA, Adiguzel A, Nadaroglu H, 2015. Biochemical evaluation and green synthesis of nano silver using peroxidase from Euphorbia (Euphorbia amygdaloides) and its antibacterial activity. J. Chem., 486948: 7.

Ciloglu D, 2017. An experimental investigation of nucleate pool boiling heat transfer of nanofluids from a hemispherical surface. Heat Transfer Eng., http://dx.doi.org/10.1080/01457632.2016.1212571.

Ciloglu D, Bolukbasi A, 2015. A comprehensive review on pool boiling of nanofluids. Applied Thermal Engineering, 84: 45-63.

Ciloglu D, Bolukbasi A, Cifci H, 2015. Experimental investigation of pool boiling heat transfer in nanofluids around spherical surfaces. Journal of the Faculty of Engineering and Architecture of Gazi University, 30: 405-415.
The use of a plant-based material as an efficient coolant in heat transfer applications is an exciting development for heat transfer engineers.

Acknowledgments: This research was supported by the BAP-2012/490 project of the Research Fund of Ataturk University.

\section{Nomenclature}
A surface area, $\mathrm{m}^{2}$
$\mathrm{h}$ heat transfer coefficient, $\mathrm{W} \mathrm{m} \mathrm{m}^{-2} \mathrm{~K}^{-1}$
I input current, A
$\mathrm{q}^{\prime}$ heat flux, $\mathrm{W} \mathrm{m}^{-2}$
$\mathrm{T}$ temperature, ${ }^{\circ} \mathrm{C}$
$\mathrm{U}$ input voltage, $\mathrm{V}$
s surface
sat saturate

Collin B, Auffan M, Johnson AC, Kaur I, Keller AA, Lazareva A, Lead JR, Ma X, Merrifield RC, Svendsen C, White JC, Unrine J.M., 2014. Environmental release, fate and ecotoxicological effects of manufactured ceria nanomaterials. Environ. Sci.: Nano, 1: 533-548.

Harish G, Emlin V, Sajith V, 2011. Effect of surface particle interactions during pool boiling of nanofluids. Int. J. Therm. Sci., 50: 2318-2327.

Herna'ndez BA, Gonza'lez R, Viesca JL, Fernández JE, Di’az FJM, Machado A, Chou R, Riba J, 2008. CuO, ZrO2 and ZnO nanoparticles as antiwear additive in oil lubricants. Wear, 265: 422-428.

Keller A, McFerran S, Lazareva A, Suh S, 2013. Global life cycle releases of engineered nanomaterials. J. Nanopart.Res., 15: 1-17.

Kim SJ, Bang IC, Buongiorno J, Hu LW, 2007. Surface wettability change during pool boiling of nanofluids and its effect on critical heat flux. Int. J. Heat Mass Transfer, 50: 4105-4116.

Liu ZH, Qiu YH, 2007. Boiling heat transfer characteristics of nano fluids jet impingement on a plate surface. J. Heat Mass Transfer, 43: 699-706.

Mourgues A, Virginie H, Muller T, Marylise CC, 2013. Boiling behaviors and critical heat flux on a horizontal and vertical plate in saturated pool boiling with and without $\mathrm{ZnO}$ nanofluid. Int. J. Heat Mass Transfer, 57: 595-607.

Ngoc ND, Minh DL, Quang KN, Byung SK, 2011. UV absorption by cerium oxide nanoparticles/epoxy composite thin films. Adv. Nat. Sci., Nanosci. Nanotechnol., 2: 045013.

Okawa T, Takamura M, Kamiya T, 2012. Boiling time effect on CHF enhancement in pool boiling of nanofluids. Int. J. Heat Mass Transf., 55: 2719-2725.

Raveshi MR, KeshavarzAM, Mojarrad S, Amiri S, 2013. Experimental investigation of pool boiling heat transfer enhancement of alumina-water-ethylene glycol nanofluids. Exp. Thermal Fluid Sci., 44: 805-814. 
Sarafraz MM, Hormozi F, 2014. Nucleate pool boiling heat transfer characteristics of dilute $\mathrm{Al} 2 \mathrm{O} 3$-ethyleneglycol nanofluids. Int. Commun. Heat Mass Transf., 58: 96-104.

Shahmoradi Z, Etesami N, Esfahany MN, 2013. Pool boiling characteristics of nanofluid on flat plate based on heater surface analysis. Int. Commun. Heat Mass Transf., 47: 113-120.

Sheikhbahai M, Esfahany MN, Etesami N, 2012. Experimental investigation of pool boiling of Fe3O4/ethylene glycol-water nanofluid in electric field. Int. J. of Therm. Sci., 62: 149-153.

Tiwari AK, Ghosh P, Sarkar J, 2013. Performance comparison of the plate heat exchanger using different nanofluids. Exp. Therm. Fluid Sci., 49: 141-151.
Vahabi K, Dorcheh SK, 2014. Biosynthesis of silver nanoparticles by Trichoderma and its medical applications, in Biotechnology and Biology of Trichoderma, Gupta VK, Schmoll M, HerreraEstrella A, Upadhyay RS, Druzhinina I, Tuohy MG, Eds., chapter 29, 393-404, Elsevier, London, UK.

You SM, Hong YS, O'Connor JP, 1994. The onset of film boiling on small cylinders: local dryout and hydrodynamic critical heat flux mechanisms. Int. J. Heat Mass Transf., 37: 2561-2569.

Zhao C, Chen YK, Ren G, 2013. A study of tribological properties of water-based ceria nanofluids. Tribol. Trans., 56: 275-283. 